

\section{FOLKLORE}

\section{a fully peer-reviewed international journal of folklore and folkloristics published three times a year}

Editor

Patricia Lysaght University College Dublin, Ireland

Associate Editor

Caroline Oates The Folklore Society, London, UK

Assistant Editor

Jessica Hemming The Folklore Society, London, UK

Editorial Assistant

Lizanne Henderson University of Strathclyde, UK

Book Reviews Editor

Jessica Hemming The Folklore Society, London, UK

Editorial Board

Theresa Buckland Department of Performing Arts, De Montfort University, Leicester, UK

Sandy Hobbs School of Social Studies, Paisley University, UK

Robert McDowall The Folklore Society, London, UK

W. F. Ryan President of The Folklore Society, London, UK

Jacqueline Simpson The Folklore Society, London, UK

Juliette Wood School of Welsh, University of Cardiff, UK

International Advisory Board

Marion Bowman Vice-President of The Folklore Society, England

Ulrika Wolf-Knuts Finland

Keith Cunningham USA

Alexander F. Fenton Scotland

Diane Goldstein Canada

Galit Hasan-Rokem Israel

Reinhard Jöhler Germany

Bengt af Klintberg Sweden

Christine Shojaei Kawan Germany

- Folklore is one of the earliest English-language journals in the field of folkloristics, first published as The Folk-Lore Record in 1878.

- Folklore publishes ethnographical and analytical essays on vernacular culture worldwide, specialising in traditional language, music, song, dance, drama, narrative, foodways, medicine, arts and crafts, popular religion and belief. It reviews current scholarship in a wide range of adjacent disciplines including cultural studies, popular culture, cultural anthropology, ethnology and social history.

- Folklore prides itself on its special mix of reviews, review essays, bibliographies, analysis, ethnography, debate and talk-back; its combination of European and North American approaches to the study of folklore; and its coverage not only of the materials and processes of folklore, but also of the history, methods and theory of folkloristics.

- Folklore aims to be lively, informative and accessible, whilst maintaining high standards of scholarship.

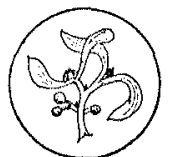

Folklore is the journal of The Folklore Society

Founded in 1878, The Folklore Society (FLS) was one of the first organisations in the world devoted to the study of traditional vernacular culture. Its objectives are to foster folklore research and recording worldwide, and to make the results of these studies available to all persons whether members of the society or not.

In addition to Folklore, personal subscribers receive FLS News, preferential rates for some conferences, lectures, books and other publications; also access to the FLS's substantial library and archives on application to the librarian or archivists. For information phone 0207862 8564, e-mail: enquiries@folklore-society.com; or visit the FLS website at: http:/www.folklore-society.com

Front Cover: Back Rider. Woodcut by Maurice Sand. From George Sand, Légendes rustiques (Paris 1858). See within: Willem de Blécourt, "I Would Have Eaten You Too": Werewolf Legends in the Flemish, Dutch and German Area, Figure 2. 


\title{
"I Would Have Eaten You Too": Werewolf Legends in the Flemish, Dutch and German Area
}

\author{
Willem de Blécourt
}

\begin{abstract}
A geographical approach to werewolf legends results in the identification of a major werewolf area, stretching from mid-Germany into the Netherlands and Belgium-despite profound differences in the intensity of collecting the legends. Within this area there were people who were experiencing nightly encounters, especially with back-riding werewolves, and they advised each other about how best to overcome the beasts. Migratory legends, such as the Werewolf Lover/Husband and the Hungry Farmhand, show a different distribution: they exceed the boundaries of the core area but adhere to the national border between Germany and the Netherlands. As is the case with the nightmare, the meaning of the werewolf metaphor turns out to be sexual: "werewolf" denotes a sexually deviant man.
\end{abstract}

\section{Introduction}

In the volume of German legends collected by the Brothers Grimm in the second decade of the nineteenth century, the following werewolf tale is presented:

\begin{abstract}
A soldier told the following story which had apparently happened to his own grandfather. His grandfather was said to have gone into the forest to cut wood, together with a friend and a third man who was always suspected of having something wrong with him, but what this was, was not exactly known. When the three had finished their work and had become tired, this third man suggested they have a short sleep. This then happened and everyone lay down on the ground; but the grandfather had only pretended to sleep and had opened his eyes a little bit. The third man had looked all around to see if the others were asleep and, when he thought they were, he had taken off [or put on] a belt and had become a werewolf; but this werewolf did not look like a natural wolf but slightly different. Thereupon he had run off to a field nearby in which a young foal was grazing, which he attacked and then devoured every scrap of. Thereafter he had returned, had put on [taken off] the belt and again lay before them in human shape. After a little while they had all got up together and had returned to the town and, when they were at the gate, the third man had complained of stomach-ache. Whereupon the grandfather had whispered secretly into his ear, "When one devours a whole horse ..."; the third man, however had replied: "Had you said this to me in the forest, you would not be able to say this now" (Grimm and Grimm 1976, no. 214). [1]
\end{abstract}

This is a version of one of the most popular werewolf legends in Germany, although it is a mixture of two (or more) different accounts and the belt definitely needed to be worn rather than taken off. The popularity of what I call "The Hungry Farmhand" legend since it is usually told about agricultural labourers 
rather than woodcutters, was already recognised in the 1860 s, when it was described as the "most common" werewolf story (Hertz 1862, 80). This acclamation may have been partly due to the text's inclusion in the Grimm collection, for the authority of the brothers was such that any subsequent collection would have looked incomplete without this particular narrative. Other legends which might have been equally vibrant were less likely to be readily legends which migh

Studies of werewolf legends are extremely rare. Since notions about werewolves
identified as such. are not the same everywhere, I have opted for a description and analysis of folklore material from the north-west corner of the European continent, simply because I am most familiar with it. [2] What follows is a rough description of the material, including the main legend types, ordered by the same principle of distinguishing between mere stories and actual experiences as applied in the case of nightmares (de Blécourt 2003). The question then is: what was in people's minds when they talked about werewolves?

\section{Collecting Werewolf Legends}

Other nineteenth-century German collections, which contain between four and seven werewolf texts, are somewhat more relevant to werewolf research than the publications of the Grimms. If one wants to compile a geographical overview of werewolf legends, however, those collections are still insufficient. It was only in the 1930s that German folklorists began to publish werewolf legends in a more extensive fashion. Matthias Zender's 1935 collection from the Westeifel contains twenty-eight such texts (1980, nos 1130-51), while Wilhelm Bodens's collection from the Lower Rhine area has as many as thirty-nine examples (1937, nos 73270 ). This increase in werewolf texts was not just a matter of the greater willingness of informants to overcome their reluctance and divulge their knowledge about topics classified as superstitious (compare Müller 1937, 63-4); rather the skill of the collector was decisive, especially his insight that legends were a part of daily speech. Nevertheless, even though the material published in the 1930s was more extensive than what had appeared in print in the nineteenth century, it was still no more than a selection of what was available.

The Central Archive (ZA) for German Narrative Research in Marburg houses about two hundred and fifty nineteenth-century and twentieth-century werewolf texts collected from the German language area. Some of these were copied from published legend collections, while others represented unpublished sources; some were in dialect and some others were literary adaptations of what were presumably oral sources. The largest unpublished individual collections are those by Gustav Meyer for Holstein, which contains seventy-one werewolf texts (compare Meyer 1929), and Wilhelm Bodens for a small area north of Aachen, which has fifty. These numbers do not reveal anything about the quality of the research. Will-Erich Peuckert's published collection of tales from Lower Saxony (not incorporated into the Central Archive) comprises fifty-five werewolf texts and is based on published sources. Although it covers the relatively large region between the rivers Ems and Elbe, and is naturally more varied in content than a collection made by an individual collector, it was not the result of exhaustive interviewing (Peuckert 1966, nos 1391-1424). In terms of the whole of Germany,

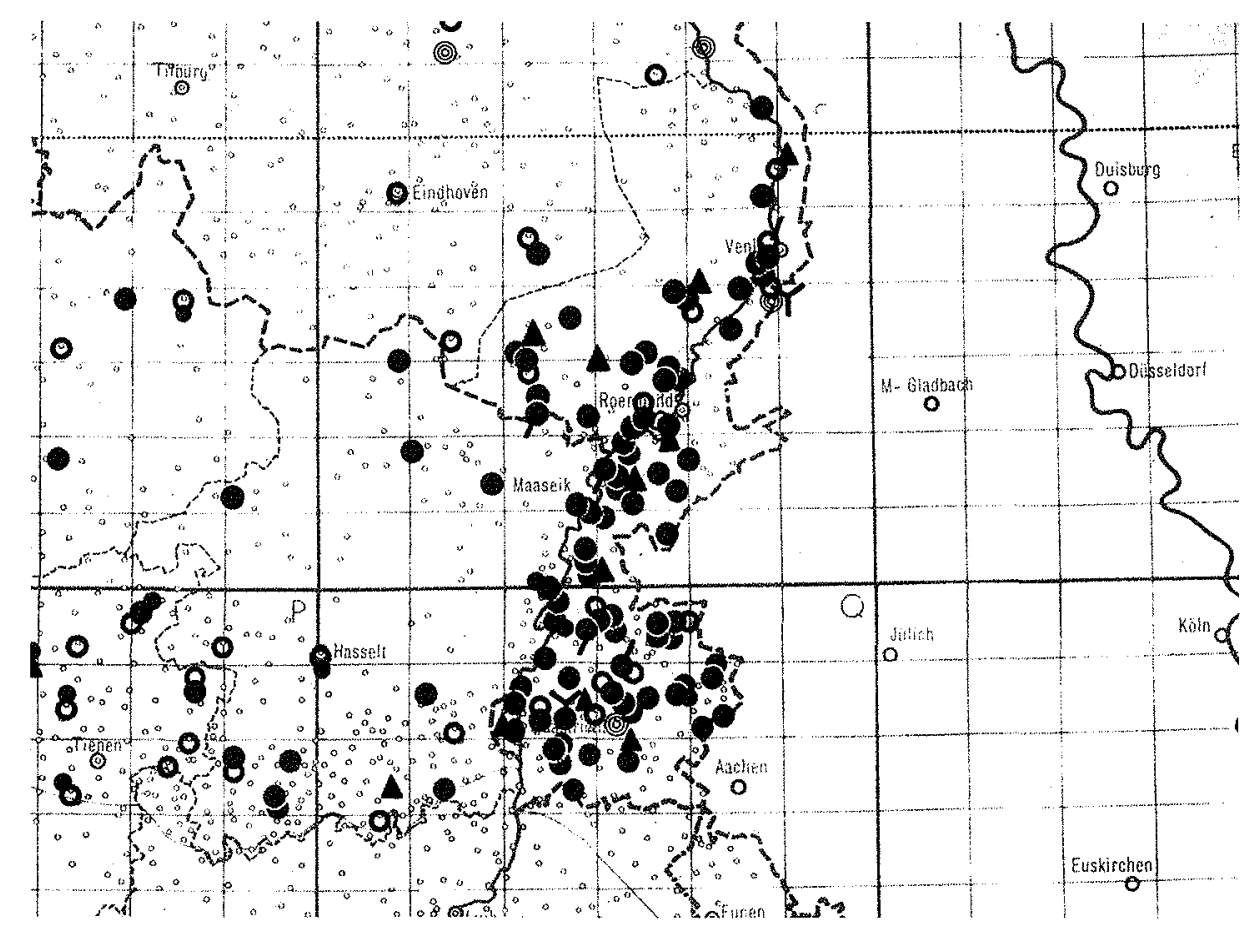

Figure 1. Part of a Map from the Dutch Folklore Atlas (1954) showing the responses to questions about werewolf beliefs in the province of Limburg. A closed circle indicates the places where a back rider was mentioned.

the total number of werewolf legend texts probably does not exceed four hundred. To put these numbers in perspective: the Belgian folklorist Fons Roeck based his 1967 werewolf thesis covering the Netherlands and Flanders (here used in the sense of the Dutch-speaking area of Belgium), on 1,170 texts, and this entire area is significantly smaller than Germany. However, since the Dutch total includes the responses to the survey held for the purposes of the Folklore Atlas (see Dekker and Schell 1989), while the German one does not the actual numerical difference is less pronounced. Nevertheless, the number of werewolf texts in individual Dutch and Flemish legend collections still exceeds those in the majority of the German ones. At the time Roeck was working on his thesis, he had about six hundred unpublished Flemish legend texts at his disposal, but did not have access either to the Dutch texts collected in the 1960s or to the later Belgian ones. Each of the largest Dutch collections-those by Henk Kooijman and Engelbert Heuperscontain over one hundred werewolf legends. Eight other collectors, working along the eastern border of the Netherlands, between Enschede and Maastricht, together recorded another one hundred and seventy-five legend texts about the beast. Flemish and Dutch legend collecting only got under way in a relatively late period, but the resulting collections certainly surpassed most of the German ones, both quantitatively and qualitatively. [3] After the Second World War, German folklore studies were deemed to have been contaminated by Nazi ideology, and when their scope and content were redefined in the 1960s, the study of traditional legends, including those relating to werewolves, declined significantly. Occasional fieldwork activity, such as that carried out by Gustav Grüner in 1956 in Waldeck, 
resulted in only fourteen werewolf texts being collected. As extensive research on the werewolf theme was not carried out in many regions of Germany, it is thus not always easy to determine from the available texts whether the lack of particula lo in particular, more werewolf legends would certainly have been found there if
folklorists had looked harder for them (Höck 1985; compare Franz 1917).

\section{The Back Rider}

The work of Fons Roeck provides a good starting point for studying this material He identified four main werewolf themes in his corpus, which he named: the Werewolf Lover, the Oven Legend, the Wound Legend, and the "Back Rider" Legend. The Werewolf Lover is basically the same narrative type as the Werewol Husband migratory legend (Christiansen 1958, ML 4005), except that in the Dutch language a lover takes the place of the husband. The Oven Legend relates how th werewlf skin or belt of a farmhand is discovered, often in a hollow tree, and is subsequently burned. While this is being done the farmhand is sent away. He subsequently burned. While this is being done the farmhand the destruction of manages to return in the nick of time but usually cannot prevent the destruction of his means of metamorphosis and, in the end, is relieved to be freed from his condition (for a German he is struck with a piece of wood, stabbed with a knife, or wounding the man is recognised and made harmless. The otherwise attacked. In this way the man is recognised and me carried is so typical and lets himself be carried is so typical of continental European material that in the Motif Index he is classified under the
German dialect term "Huckauf" (Thompson 1955-58, F472).

In the Dutch region bordering on the Rhine and Germany, this sort of werewolf was talked about in the following terms (the original is in dialect)

My father told me: his mate, he had said to him he wasn't afraid of anything, neither by day nor by night. But once he came to me and then he was really frightened. Then I said: “What's the matter, man?" "I will tell you something, John Rot. I went from Lobith to Didam in the middle of the night. And my dear man, I didn't suspect anything. And then there was a murmur behind me, as if a wind arose, and something flew onto my nape. I could see the paw hanging over my shoulders and sweat ran from my neck and ears. I didn't know what to do, and onought: God, what's happening to me? Then I arrived at the church in Didam, in front of the thought. God, whats happening of me. Then I lost him. I went home with dread in my shoes. old church, and then he jumped orf me. Then I lost ight Iays because of it I told many people And, my dear man, live been ill and miserable for eight days becul of this. They heeded it all and no longer dared to pass that road at night because of what happened
to me!" (Tinneveld 1976, no. 78).

In this relatively long narrative the creature on the man's back is never called a werewolf (the mention of the paw is clear enough evidence that he is), but in many other versions it is. This back-riding werewolf is always portrayed as being male. other versions it is. This back-riding werewolf is always portrayed as being male.
In the Netherlands, the tradition is found mainly in southern Guelders and in the province of Limburg. A few early twentieth-century reports from the northeastern provinces of Groningen and Drenthe show that he had a wider distributional reach at one point. The Belgian back rider tradition is concentrated in the Belgian province of Limburg (west of Dutch Limburg). Further west, the back-riding province of Limburg (west of Dutch Limburg). Fur burg and in the adjacent area around Aachen, the dialect term used for the creature is stüpp (Grober-Glück 1964/65, 130 and map; ZA Bodens 1083419, 1083420; collection Brouwers no. 23). He was also known as stoepstaart (staart = tail) in The Betuwe, southwest of Arnhem, in the 1830s (Roeck 1967, 229). Words like stüpp or kludde are primarily synonyms for werewolf; this is evident from their appearance in the same kind of legends and by their interchangeable use. Pec the term Boxenwolf (Boxen = trousers) for the werewolf. But if an even broader geographical perspective is taken, Werwolf and related terms are only some of the names for the back rider. As the German Folklore Atlas indicates, Werwolf was used in the Rhineland and east of Cologne - the easternmost record is from near Kassel. It was, furthermore, very frequently found in the county of Schaumburg, west of Hanover (Grober-Glück 1964/65, 128-9). As was the case with the Netherlands, it has to be assumed that this map marks a stage in the decline of the werewolf has to be assumed that this map marks a stage in the decline of the werewolf early twentieth century (Lohmeyer 1920, 47). In general, however, the back rider phenomenon was known throughout Germany and was more often referred to by a name denoting a sort of man (Hehmann, Feuermann, Wassermann), rather than particularly in midwestern Germany, that the werewolf concept had become strong enough to lend its name to the back rider. In southern Germany, the werewolf had never become incorporated into daily speech, and it, thus, comes as no surprise that back riders went by other names, such as Pudel. In north-eastern Germany, the back rider was merely called "back rider" (Aufhocker), or was regarded as some sort of ghost. While a werewolf tradition was present and while people had even been prosecuted in the late seventeenth century for being a werewolf, the werewolf back rider never materialised there.

Roeck took the back-riding werewolf as an example of the disintegration of the werewolf legend, and of the blurring of boundaries between the werewolf and other figures. His conclusion "that back-riding was originally no part of the werewolf legend" (Roeck 1967, 267) echoes Müller's thesis that this was a new component, taken from the nightmare (Müller 1937, 59). This argument is incorrect, however, as the nightmare is said to suffocate people when they are lying in bed, not when they are walking abroad at night. Moreover, on the evidence of the legends, the connection between nightmares and werewolves is restricted to the coastal area extending from Frisia to southern Sweden. It is, thus, absent in the area of the back-riding werewolf. Roeck's opinion also stems from a curious failure to accept the description of the werewolf as given by informants. In Belgian Limburg, where Roeck carried out his own fieldwork, the main characteristic of the werewolf was that of riding on a walker's back. In the adjacent Dutch regions and in the lower German Rhineland, as well as in Westphalia and Waldeck, one informant after another described the werewolf in similar fashion (Müller's research is lacking in this respect). Recently, Strube (2000) has at least acknowledged that the back rider is a separate kind of werewolf concept from the bloodthirsty cattle-"consuming" one.

Since back-riding is also attributed to other, mostly local, legend figures, Roeck suspected that this characteristic indicated the existence of an anomaly in the werewolf traditions, and then simply interpreted the presence of those other figure: as a decline of werewolf lore $(1967,266-8 ; 1968$, col. 151$)$, rather than as a sign that 


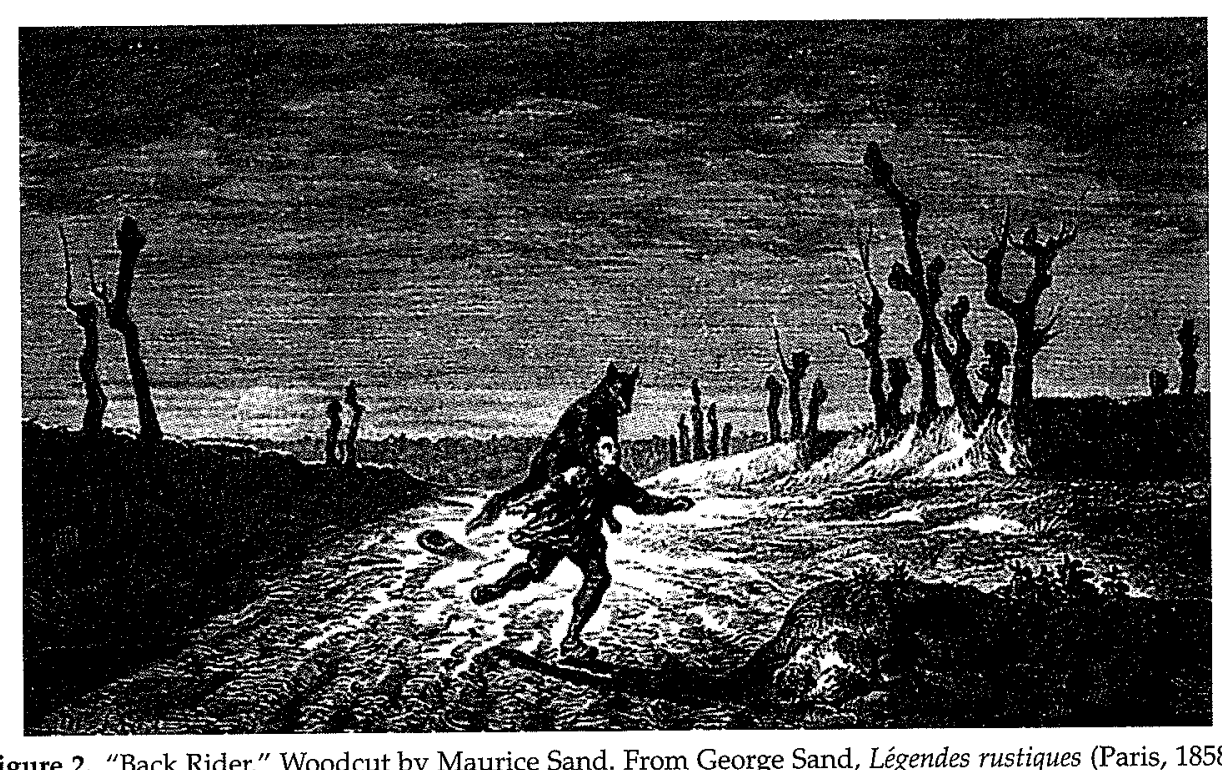

Figure 2. "Back Rider." Woodcut by Maurice Sand. From George Sand, Légendes rustiques (Paris, 1858).

the werewolf did not lend his name to the back rider notions everywhere. To disregard the back rider as an essentially regional form of the werewolf concept presumes the presence of an original cannibalistic or, at least, carnivorous werewolf throughout the whole of Europe-which is not the case. The other back-riding figures are mainly symbolic equivalents of the backriding werewolf; they represent the limits of the distribution of the term werewolf for the back rider rather than its decline. Roeck supported his argument by pointing to the relatively late appearance of the back rider in legend collections-in Flanders this happened only at the end of the nineteenth century. This observation does not carry much weight either, given that the early Flemish folklorists concentrated on narratives rather than on random motifs. German folklorists recorded the back-riding werewolf motif in the middle of the nineteenth century at the same time as when they recorded other werewolf legends (Lyncker 1854, 108; compare Hertz 1862, 87; Peuckert 1966, 481-2).

While the Werewolf Lover Legend and the Oven Legend can be considered as While the Werewolf Lover Legend and the Oven Legend can be considered as
tale types or migratory legends, the other two themes-back-riding and wounding - are better classified as memorates since they refer more to experiences than to stories. The Hungry Farmhand, in turn, constitutes another legend type, which Roeck failed to identify since it had not crossed into Limburg. Yet another type, which can be observed that of the child who puts on the Yet another type, which can be observed-that of the child who puts on the
werewolf belt of one of his parents-appears to be rare, as only a few versions have been recorded (Zender 1980, no. 1134; Bartsch 1879, 149; Hertz 1862, 80)

\section{Husbands, Lovers and Labourers}

The Werewolf Husband narratives are divided into two main groups of legends, one of which is in the German language and the other in Dutch. The German subtype deals with how a man abandons his wife, comes back as a werewolf, bites into her skirt, petticoat, or apron, or some other piece of clothing, then goes off again, and comes back in human form, and is later revealed as the werewolf by the remnants of her clothing evident between his teeth. I have found about thirty-five German-language versions of this story, from the Rhineland in the west to East Prussia, and, in at least half of them, the colour of the skirt or petticoat is red; in the others, no colour is mentioned. Sometimes it is explained that the werewolf had a premonition, or that he felt an urgent need, or that he was "compelled by an inner force," and thus could warn his wife in advance of the event (Peuckert 1966, $503-5$ ). In a minority of the tales (five), a father and daughter take the place of the husband and wife. Near the Dutch border, a couple of versions in which a boy is walking with his girlfriend are found (for instance: Bodens 1937, no. 742). This is the Dutch language version of this legend: the Werewolf Lover. This version also contrasts with the German one in that the girl usually finishes the relationship on discovering the threads between the lover's teeth. The one Dutch instance in which a married couple figures was recorded on the German border; here the colour of the woman's petticoat is again red, something which is a much rarer occurrence in the Netherlands than in Germany (Krosenbrink 1968, 204).

There are as many Dutch versions of the Werewolf Lover as German ones. In Flanders, many more versions of this legend have been recorded-forty-two alone in the province of Antwerp. One of them goes as follows:

Werewolves are punished people, who change into an animal at night. That lasts for about an hour, then they turn into humans again.

Once there was one and he was on his way home with his girlfriend from the fair at Baal. He kept talking about ghosts and the girl did not like it very much. When they had been on their way for a while, he had to go to defecate in the bushes. He told his sweetheart: "When you way for a while, he had to go to defecate in the bur

encounter something, just throw off your apron.

When this guy was sitting in the bushes, he felt the evil rising. The girl saw something approach and she threw her apron at it and then it was gone. When he returned he asked whether she had seen anything. "Yes," she said, "it was an animal, but I can't tell what kind." The boy laughed about it. "But I did have to throw off my apron," she said.

When they got home, he stayed to have a drink - they had an inn - and then she noticed that there were still pieces of apron between his teeth. She became ill because of that and died (van den Berg 1981, 132)

The structure of the legend in Antwerp is similar to the other Dutch-language versions, from the lovers' walk to the discovery of the threads and the breaking of of the engagement (although the girl seldom dies; compare van den Berg 1993, 1858). The recorded number of legends and their distribution is dependent, as usual, on an uneasy combination of how thorough the research was and how many variants were available. What stands out here is the sharp division between the subtypes along national borders-in this instance between Germany, on the one hand, and the Netherlands and Belgium on the other. In the case of an oral tale one would expect that subtypes in dialect would cross the borders. This division, therefore, suggests that printed versions in the national language preceded oral distribution. Although broadsheets travelled faster than oral tales, it still does not show how long it took for a story to migrate. It is, therefore, impossible to reach a conclusion with regard to its age from its distribution pattern alone, or to discover the region from which it originated, or the direction of its movement. The latter can only be guessed at on the basis of careful interpretation.

The typical elements of the Hungry Farmhand legend are the labourers, most often mowers, and their afternoon sleep, during which one of them puts on a belt, 
becomes a werewolf, and devours a foal. One of the others only pretends to sleep and thus sees everything that happens. After the werewolf returns to his comrades and complains about having a stomach ache, or mentions a lack of appetite, he is told "no wonder if you have just eaten a foal." He then responds: "if you had told me earlier, I would have eaten you too." In some versions, however, hou leaves forever:

One of the farmhands, who had pretended to be asleep, had seen everything but told the others When they were lying near the fire, the werewolf shuddered and said: "I don't know why I feel so nauseous." "Well," said the farmhand who had stayed awake, "who wouldn't be nauseous with a whole foal inside [him]." "You're lucky," shouted the other, "that you did not tell me this before!" and with these words he slipped on his belt, instantly became a wolf, rushed into the wood, and this was the last his comrades ever saw of him (Kuhn 1843, no. 243).

This legend was especially popular in northern Germany. Peuckert collected twenty-one published versions from Lower Saxony, and Meyer recorded twelve oral versions in Holstein-which constituted a mere seventeen per cent of all his unpublished werewolf texts. This northern concentration is reinforced by versions from Pomerania and Poland, and by the legend's prevalence in Sweden. In the Lower Rhineland, it was as rare as in neighbouring Limburg. Bodens's unpublished collection from the area north of Aachen, does not contain a single example of it, and the few versions he published from more northern places are slightly distorted. In one, a cow is eaten instead of a foal and the werewolf is later exposed by the pieces of meat stuck between his teeth. In another, a man, not a wolf, goes into the field to torture the foal and eat it (Bodens 1937, nos 739 and 745, and compare no. 749). In one rare version from the Eifel, on the other hand, most of the usual elements are present again; the only difference is that the men are not taking an afternoon nap but are on their way back from Trier, at night (Zender 1980 , no. 1148). North German versions, however, generally show few variations which, together with the strong German language prevalence of the story, again suggests that it circulated in print. The very few Dutch oral versions (for instance, Tinneveld 1976, no. 21) clearly have a German origin.

\section{Werewolf Geography}

Although the distribution of werewolf migratory legends is geographically distinct, the fact that they are primarily stories means that they cannot be used as the basis for determining which areas had an active werewolf discourse. For this, other material is needed, such as back rider texts and accounts of the subduing of the creature. The central werewolf area that can then be distinguished constitutes a more or less uninterrupted space, roughly delineated by the line Kassel-Hanover in the east Hanover-Osnabrück-Arnhem in the north, and Eindhoven-Luik in the west (see Figure 3). The southern border is somewhat more vague, and there are also no reports of the werewolf tradition from the cities and the industrial region along the Ruhr. Characteristic of the werewolf complex in this central area is the particular combination of motifs. At the core is the back-riding werewolf; when werewolfing he wears a belt or a skin, or something else with which to cover himself. This kind of werewolf is predominantly described as being male and though his disguise suggests that becoming a werewolf is a voluntary act, it is also often depicted as resulting from an involuntary drive. He can be stopped if he is stabbed with a knife, or if he is beaten. As an informant of Bodens related: a man put on a wolf's skin to frighten others, but a farmer cut him with his knife until blood flowed, and he thereupon recognised him as one of his friends (Bodens 1937, no. 751). Or, as it was told in the Peel area, west of the river Maas:

They used to tell that there were a lot of werewolves between Hamont and Dorplein. My father told that he had seen a werewolf on his way to work. The creature suddenly jumped on his back and my father had to carry him almost all the way to the zinc plant. You could expose them, they said, when you put a knife between their ribs. Then you could see immediately who it was (collection Daniels no. 646)

The complex also includes the Oven Legend, which is only underlined by a version from Jülich without an oven, in which a boy falls to his death when his belt is discovered in a hollow tree (Henßen 1955, 107-8). There are further reports, from Lippe (Scheffler 1994, 285), as well as from Limburg, about how young men were warned not to play at being a werewolf, because someone who had done this had been beaten to death (Roeck 1967,410). The imitating of a werewolf's actions suggests either that those who did this did not take werewolves seriously, or that they were intrigued by them; it also shows that the werewolf concept was sufficiently vivid to be imitated:

Nor was the werewolf forgotten when people gathered around the hearth in winter. When they talked about "carrying the werewolf," it was always good for a laugh. Once the boys realized that a gullible, anxious boy had to walk a lonesome road in the evening, they made him "carry the werewolf." One of them hid beside the road and jumped suddenly on the back of the poor

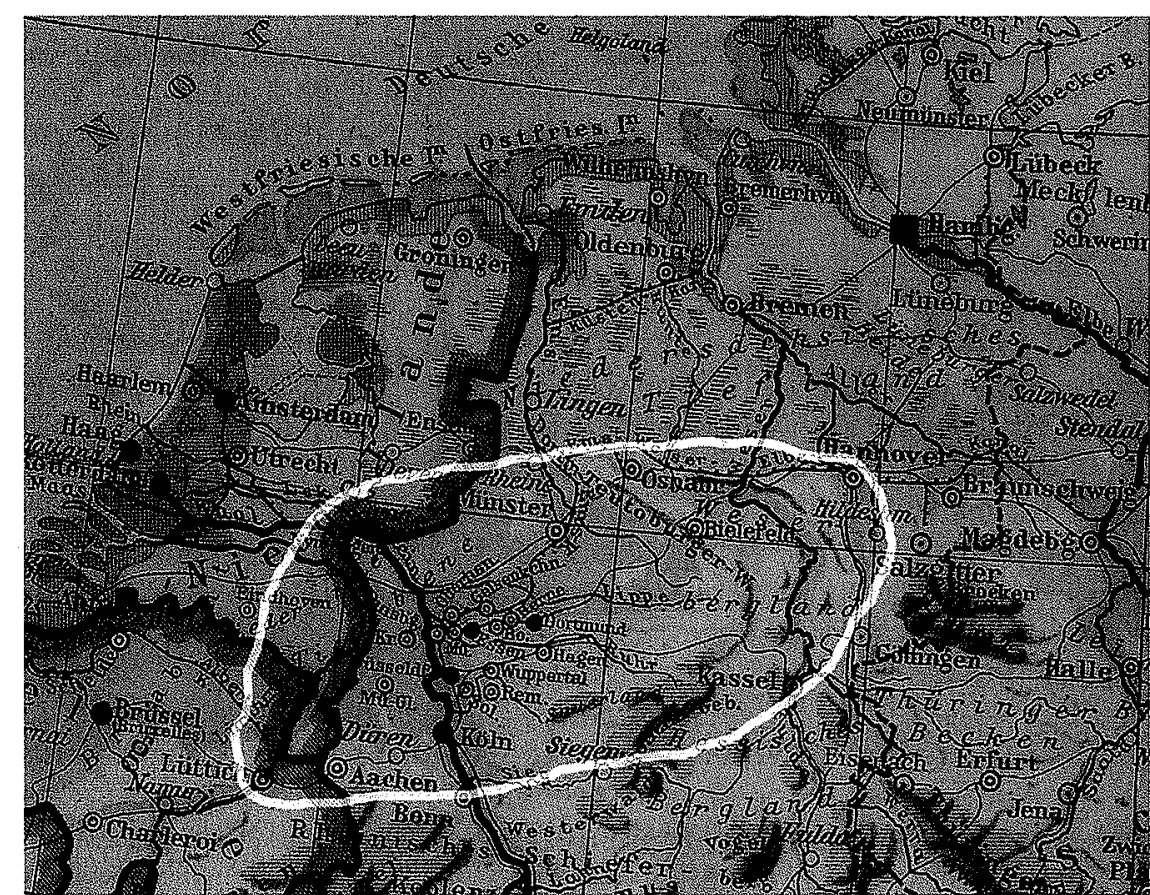

Figure 3. Core area of the werewolf complex dealt with in this article. 
boy and let himself be carried for a stretch of the way. The boy was under the illusion that he had to carry a werewolf and he was frightened and sweating. It was common knowledge who had carried the werewolf (de Blécourt 1981, 249; the original text dates from 1944).

Both folklorists and their informants were outspoken about the werewolf's gender. As Grüner observed about Waldeck: "It is almost always men who change into a werewolf" (Grüner 1964, 40). Bodens found people in the Lower Rhine region who told him that women had the power to bewitch and men to werewolf (Bodens 1937, nos 732 and 734), and the same was said across the border in the Netherlands (Dinissen 1993, no. 26). "Trouser wolves" were always men (Strube 2000,23 ). Roeck goes so far as to state that, apart from one or two aberrations, all werewolves were men, and that it was mostly men who talked about them (1967, 375-6). He is probably right, although there are some exceptions where the narrators of the Werewolf Lover legend are concerned. Since the few werewolf legends in which a female creature appears stem from parts of the central area that have not been as well researched as the Belgian, Dutch and Lower Rhine regions, it is difficult to assess them properly. They may have been rare remnants from witch trials, or they could also possibly be interpreted as a sign that werewolf lore was in decline, and that it was being contaminated by the witchcraft discourse.

Certainly, by the twentieth century, werewolf lore showed signs of weakening in some parts of its core area. According to German folklorists, the werewolf tradition in the Rhineland, which was still alive in the nineteenth century, had almost died out in the twentieth. In Oberbergen (east of Dortmund), it was only possible to record a handful of werewolf legends there in the twentieth century (Kaufmann 1965, 4-5, based on Henßen; compare Schell 1897). In the regions bordering on the central area some characteristics are still recognisable, but the back rider and the counter measures are lacking. In the Dutch province of Utrecht and in neighbouring western Guelders, werewolves were male, but the Oven Legend was unknown there. A maid who still remembered the back rider originally came from a place just east of Arnhem (Heupers 1979-84, no. 1695). Heupers's only other informant-a night watchman from Doorn-who mentioned the back rider, situated the creature in the past: "I can't say exactly," he said in 1969, "it was told so long ago" (Heupers 1979-84, no. 3640). In the Kempen, one informant of Daras's, when talking about the back rider, also pointed eastwards, to Limburg, which he regarded as "far from his home area." Another indication of a threadbare tradition in the Kempen is that threequarters of the legends told to Daras were versions of the Werewolf Lover legend (Daras 1964 , nos 2177-2188iii). At the eastern end of the central area, there are also signs of a diminishing werewolf culture. Although the back rider was known in Hesse, the notion of throwing steel over a werewolf, instead of hitting him with it, seems a rather impractical counter measure.

\section{A Matter of Meaning}

Psychoanalysts have readily interpreted the werewolf as a sexual creature. Their empirical basis, however, is too narrow to justify simply transferring their insights to legends-especially, since to them, sexual deviancy only enters the picture in the form of excessive male heterosexuality. The older folklorists in their turn hardly ever connected their own findings about the werewolf with regional attitudes to a specific kind of deviant sexuality. Odstedt went the farthest in this respect when she concluded: "Some of these legends suggest that they are expressions of erotic fantasy. This entire complex of ideas is shaped by certain sexual pathologies" (Odstedt 1943, 226). To reach such a conclusion for the German and Dutch werewolf legends one has still to take into account the actual texts and their regional variation. Moreover, any interpretation must draw on as many different forms of speech and narrative genres as possible. Sayings-for instance, those comparing someone with unruly hair to a werewolf (Survey 1937; K 178; Kooijman 1988, no. 842)-may be rather revealing. This also entails the incorporation of Roeck's unclassified tales into the argument which tell of freeroaming werewolves, and of those who located themselves in particular places in order to taunt people as they passed by (Roeck 1967, 271). These werewolves are merely a paler version of those in the main legends. It is also means that the kinderschrik (bogeyman), the figure adults use to frighten children, must be taken into account. Roeck considered this a pedagogical device; according to him, if adults use werewolves to educate their children, they do not themselves believe in the creatures. This ties the werewolf to a "belief" instead of an expression. The question, however, still needs to be asked: what was it that children were warned about and why was a werewolf thought to be dangerous? Above all, an inclusive approach means that the back-riding werewolf cannot be ignored.

Metaphors are the basic elements of migratory legends. A literal understanding of the Hungry Farmhand as a metamorphosis is, therefore, an unlikely scenario. Even a foal has too much flesh to be eaten at once (admittedly, in some texts it is stated that only half a foal is devoured). Furthermore, the threat to eat the comrade does not make much sense when there are no other stories around of werewolves eating adults. A recent interpretation of the legend is that it is an example of a cattle-stealing werewolf, but this explanation seems rather unlikely. While it is inconsistent with the plot, it also does not provide answers to questions such as, where the foal is taken? and why the threat is uttered? (Strube 2000,19). This does not, however, eliminate theft as an additional meaning of the werewolf concept; some texts explicitly mention stealing as the main reason for the werewolf to roam around at night. According to Roeck $(1967,437)$, brigands have disguised themselves as werewolves since the medieval period, but he does not present any evidence to support this assertion, and it is possible that the notion was taken from a novel (van den Berg 1993, 1856, n. 524). As in the early modern period, examples of enrichment by virtue of being a werewolf point to contamination by notions about male witches. But if a werewolf disguise was used to cover up theft or burglary (compare Scheffler 1994, 283-5), it does not necessarily contradict or exclude a more general interpretation; it just shows that people were utilising the concept.

Another, seemingly more mundane explanation of the term "werewolf" is to regard it as a metaphor for hunger. In Hesse it was said that: "He is hungry like a werewolf"; or "someone who talks during a meal could be jokingly described as having "the appetite of a werewolf"' (Pfister 1885, 56). As Bodens observed in the Lower Rhine area: "In the more recent legends the werewolf is only the big eater" (Bodens 1934, 299; also 1937, nos 734, 736, 759 and 760). The notion of the gluttonous werewolf, however, should not be discarded, any more than that of the stealing werewolf, because we do not know the mind of every single informant. Yet, these mundane explanations remain unsatisfactory, especially since not every 
thet of glutton automatically became a werewolf. There was no need for "Werewol" af a separate concept if it was merely synonymous with hunger or stealing. The hunger could easily have been a metaphorical, sexual hunger.

Counter measures against werewolves give a good idea of the kind of creature people feared. While these measures are rarely mentioned in peripheral werewolf regions, in the central area they point less to a magical than to a physical werewolf. They also suggest the actuality of meeting a werewolf since cutting or beating him instantly leads to his disclosure as a human. This separates the wounding from the witchcraft discourse, and from notions of a second body where the wounded person is only found later, often the following day. (Conversely, when this timelag occurs in some werewolf narratives, we can assume that it has been taken from local witchcraft discourse.) The werewolf's corporality has its equivalent in the directness of daily speech. People said that someone was "able to werewolf" and that "to werewolf" was worse than "to witch" (often recorded by Heupers; see also Henßen 1955, no. 166a). Putting on a werewolf's belt thus became an act of disguising oneself rather than engaging in magical shape-shifting, as those who told the legends made sufficiently clear: "There was a man who had dressed up as a wolf," said an informant from Hesse (Grüner 1964, no. 49). In the Kempen area it was said that: "The werewolf, that was someone who could dress up as an animal" (Daras 1964, no. 2177). "Werewolves, they were people whose nature it was to dress up," Bodens heard in the German Lower Rhine area (1937, nos 751 and 763). Kooijman recorded a number of texts about a similar custom further down the river: "There used to be this guy here who dressed up as a werewolf to frighten people"; "It was a man dressed in an animal skin": "Werewolves, they were the kind that walked on two legs. It was wearing a white skin with black spots, from a cow ... They were people!"; "They walked on all fours" (Kooijman 1988, nos 1183, 1218,1308 and 1470; also nos 1523 and 2449; compare no. 1643). Many more such instances were recorded in the Dutch folklore survey, especially for the province of Limburg (compare Figure 1).

\section{Abortion and Assault}

When the Werewolf Lover legend is considered, there can hardly be any doubt that it refers to a sexual assault. A farmer from mid-Limburg expressed this notion more like a piece of oral history than as a migratory legend:

During the autumn evenings grown-up girls used to gather to preserve beans and, in winter, to spin together. Afterwards the girls drank coffee and went home. Boys who had an eye on them turned up to act as their protectors. Once five girls were on their way home. They had been troubled by a werewolf before and then they had run off in a flash. Now they were accompanied by boys, who would teach the werewolf not to attack the girls anymore. Suddenly he was there again and tried to jump on someone's back. One of the boys hit him hard on the head with a piece of wood. The werewolf dropped down and the whole group ran away anxiously. Next morning the body of a man was found behind the verge of the road, who had paid for his adventure with his life... It was a married man. According to my mother this actually happened in 1885 (collection Engels no. 32.6)

The Werewolf Lover covers different traditions in which a wife, or a girlfriend, or a child figures as the attacker's victim. Certainly, the Dutch material shows that this, more than other werewolf legends, is a female tale. Most of the versions in the eastern part of the province of Guelders were recorded from women, and, in two instances, they said that they had heard the story from their mother or grandmother (Tinneveld 1976, 102-3 and 203; collection Krosenbrink nos 110.1, 86.13 and 224.2). A cobbler in Utrecht was told the tale by his mother, as was a farmer living along the western reaches of the river Maas (Heupers 1979-84, no. 1416; Kooijman 1988, no. 1915). But the story was not exclusively associated with females; in Roeck's material, for example, male tellers dominate. Regional variation is shown in the difference between wife and lover, rather than in the setting of the encounter. The different regions in which the story circulated had different marriage customs and they were obviously reflected in it. The possibility of ending the relationship was apparently much harder in the Catholic part of the Netherlands once the wedding had taken place. [4] On a more abstract level, we can read the woven piece of cloth as representing humanity, and more specifically womanhood, as opposed to the (presumed) animal skin of the male werewolf. But in the Danish context, the interpretation of the Werewolf Husband is even more specifically tied to reproduction.

Several nineteenth-century folklorists noticed the link between the werewolf and particular circumstances surrounding childbirth. All of the three major examples of this are found along the North Sea coast and in the regions around the Sont, which are all predominantly Protestant. In these cases, there is also a strict gender division with regard to becoming a werewolf. According to an oftrecorded saying in the Dutch provinces of Frisia and Groningen, one of seven sons would become a werewolf, whereas one of seven girls would become a nightmare. In northern Germany, children born during the week of the feast of St Gallus (midOctober, equivalent to the start of winter), or during other liminal periods like Twelfth Night or St John's Day, would either become nightmares if they were girls, or werewolves if they were boys. In Denmark, the same was said to occur when women tried to escape the pains of childbirth by crawling through a horse's afterbirth (Handwörterbuch des Deutschen Aberglaubens III, cols 281 and 409, 411; IV col. 725; VI, cols 765 and 902; IX, col. 992). The nightmare was thought of as a (ghostly) female figure, who would plague a man in bed at night if he had broken off his engagement, and make him spill his semen. The werewolf is likely to have been the nightmare's male equivalent. In some legends-from eastern Denmark and southern Sweden-it is indeed hinted at that the werewolf would cause an abortion, "eat" the foetus out of the mother's body, and destroy the offspring (Simonsen 1990; Odstedt 1943, 225; Kvideland and Sehmsdorf 1991, 75-6; compare Christiansen 1958, 59-60, for versions which include a pregnant wife) The red skirt or petticoat of the German versions of the Werewolf Husband may signify the woman's menses, and the assault, then, becomes a denial of her impurity. In Denmark and in the south of Sweden (a territory which is culturally similar to Denmark), the woman throws her apron rather than her skirt at the wolf. If one follows Simonsen's line of interpretation this apron stands as a "metonym and metaphor" for the uterus. Devouring the apron is thus synonymous with devouring an embryo. In Danish tradition, this is explained as a consequence of the werewolf's birth, for his mother had forfeited her humanity when she evaded the pains of labour; by using the horse's afterbirth she had become like an animal From this perspective, the werewolf is merely regaining his humanity-not just by 
ingesting a human foetus, but also by causing the woman to suffer again (although this presumes that his wife has replaced his mother).

When the werewolf is considered as oscillating between human and animal form the Hungry Farmhand variant offers a mirror image of the Werewolf Husband drama. By devouring a foal, the werewolf is exerting the animality he received from his mother, instead of his humanity. In this way, it also becomes clear why a foal figures in the legend, rather than a sheep or a cow, for the werewolf's mother had worked horse magic. This does not necessarily exclude the sexual aspect of this kind of werewolf. Just as his sister, the nightmare, "rides" he victim and some soring in other words "rides" Bodens and Meyer, the most diligent German legend collectors, found a version in which the farmhand takes off his trousers before metamorphosing into a werewolf and "eating" the foal (Bodens 1937, no. 749; ZA 41714). A similar detail appears occasionally in the Werewolf Lover legend when the boy tells his girlfriend that he has to relieve himelf before he disappears into the wood. Where this tale with violent sexual assault on women, the Hungry Farmhand legend depicts casual afternoon sex with a farm animal. The threat on discovery is, therefore, sexual, too.

This all suggests that both the Werewolf Husband and the Hungry Farmhand legends were originally Danish rather than German. At the same time, it implies that when they were transferred into a German context, their Danish meaning was weakened and eventually lost altogether. Thus, in some areas of Hesse, the werewolf is indirectly connected to animal birth, as his belt is said to be made from werewolf is indirectly connected to animal birth, as his belt is said to be made from
the skin of either an unborn calf or donkey (Zaunert 1929, 264). When the werewolf's origin is no longer linked to a foal, the devouring of it becomes less logical. When a skirt replaces the apron the metonymy disappears, while conversely, the metaphor may broaden from abortion to general assaults on conversely

In all likelihood migratory legends about werewolves were not meant to refer specifically to an encounter with them; they were probably told as a warning, or in response to the narration of experiences. The most common form of the latter was when someone had to carry a werewolf, but in those instances it has been argued that this back rider was not a genuine werewolf but merely a watered-down version of the beast. That it concerns experiences here and not just narratives is, version of the beast. That it concerns experiences here and not just narratives is, related how he pressed his foot into the back of the knee or clung to the thighs" of his victim $(1964 / 65,129)$

\section{Deviant Sexuality}

Since migratory legends, and certainly variants of the Werewolf Lover or Husband narratives, were also told in most of the central werewolf area, can we interpre back-riding as a sexual encounter? The back rider may not immediately appear as being a sexual creature, but he is at least very corporeal. He jumps on mainly men's backs and compels them to carry him. An alternative explanation is that the back rider is a rutting ram, which sill sexual beast (Strackerjan 1909, 480; also in Peuckert 1966, 481). In some texts, the back-riding werewolf's actions are portrayed in more detail. In one region-in the north-west of the Dutch province of Limburg, bordering on Belgium-the werewolf apparently licked the face or the mouth of his victim, or "did other strange things." In texts from the same region the werewolf covered its bearer in slaver (collection Daniels nos 647 and 650). On the other side of the border, one back rider was said to have licked the neck of a man, while another urinated on his victim (Survey 1937, L320; collection Engels no. 27.8; collection Linsen no. 93.4) More to the north, in the middle of the Netherlands, the werewolf was also said to have urinated, more specifically, that he "peed in the opening of your underwear" (Survey 1937, L15). A similar event in relation to the werewolf was related by a miner in the south of Dutch Limburg province (collection Eggen no. 30.4). Bodens noted it down, too (ZA 1082822). Roeck gives some additional examples from the southern part of Belgian Limburg province, where the back-riding werewolf fouled, licked and urinated on people $(1967,278-9)$, and Peuckert found a licking werewolf in Lower Saxony narratives (1966, no. 1417).

These instances are too frequent and too widespread to be discounted as merely regional variants. If they do not appear frequently in the German material it is probably because less intensive collecting was carried out in Germany. The details thus throw light on the more general behaviour of the back rider. The act of urinating, licking, and defiling, comes as close to describing a sexual act as is possible, if it did not already actually constitute a sexual act in itself. After all, the werewolf was thought of as a man turned into an animal, and back-riding was the acknowledged sexual position of animals. The name Boxenwolf for the back rider in the regions of Westphalia, Hesse and Schaumburg, also hints at his sexual nature, for it identifies the werewolf by his trousers. Since a werewolf was not supposed to wear any trousers, they indicate that part of his body that was most active. Alternatively, the trousers may refer to the piece of clothing a Boxenwolf was most likely to attack, just as he went for the skirt in the Werewolf Husband Legend. In Minden, for example, a werewolf had scratched the breeches of his carrier (Sartori 1923, 80). In some instances, the carrier of the back rider had been warned in advance, and was advised to draw blood from his assailant. In other cases, a beating sufficed. These counter measures turn the back-riding werewolf into a man again, who is occasionally described as being naked. He is then immediately recognised and, in this way, made harmless.

In the Netherlands, the Hungry Farmhand legend may have been unknown, but there are, nevertheless, examples of the werewolf's bestiality. These stem partly from the marginal province of Utrecht, but this is compensated for by the intensity of the research. Heupers collected legends there from 1962 to 1971, which was much longer than the several weeks normally spent by the average collector in a region. Informants are also not a homogeneous mass, and they could still possess some relevant knowledge, even if it was not immediately applicable. A small number of texts mention werewolves attacking cattle, slaughtering sheep, frightening cows, and devouring foals:

A farmer in Soest was a werewolf. Nobody knew it, even his wife didn't. One once occasion the farmer stood in the stable and then he was werewolfing. The cows all jumped up together the banged their heads against the wall. It was a terrible racket. The bos was werewolfing. The bife came and stood in the door. She called the boss: 
precisely what she should not have done, for when the boss was busy werewolfing you were not allowed to call him. "Bart," she called again, and then the farmer flew out of the back door and they never saw him again. He was a werewolf (Heupers 1979-84, no. 2256).

At [a certain place] here lived a fellow of whom it was said that he could werewolf. He was a strange fellow who was capable of doing anything. For instance, he was granted a benefit from the death fund because his wife had died. But his wife was not dead at all, he had changed her into an animal, they said. A rabbit was hopping around his house and that would have been his wife (Heupers 1979-84, no. 601)

In both texts an animal figures as the substitute for a wife. In the first case the wife tries in vain to call the farmer back to humanity. To werewolf, that is to put on the skin of an animal, meant not just changing into an animal, but also identifying with an animal, and acting like one. And it did not just include sexual intercourse, it automatically implied it:

A man once told me, it had happened in Well, that man told me, he had goats and they were all bleating at night. He went to look and then someone was lying in between the goats. That was a werewolf! (Kooijman 1988, no. 1531).

To argue from a different perspective-people in the countryside were very much aware of the sexual activities of animals since they depended on them economically. Early twentieth-century sexual-advice literature often referred to the mating habits of dogs, cows, horses, and pigs, as an example to humans. Although it was taboo, bestiality certainly occurred. And if someone could not figure the procedure out for himself, the Bible provided the concept: "And if a man lie with a beast, he shall surely be put to death: and ye shall slay the beast" (Leviticus 20:15). This, of course, condemned the activity as a sin, but it also opened up the prospect of committing that $\sin$. Thus, when bestiality could not be discussed openly, it is not surprising that it was referred to with a term that already signified "to change into an animal." One informant from Frisia openly declared werewolves to be "all pansies and sodomites" (collection Jaarsma no. 485.3). To werewolf was worse than to witch because in Exodus the ban on bestiality followed the one on witchcraft (22:18 and 19).

In many werewolf texts the sexual element is not immediately evident. It has to be kept in mind, however, that sexuality was rarely openly discussed, certainly not by elderly people telling legends in the presence of a folklorist, who had just dropped by for a couple of hours to record tales about "superstition." But wild hair stands for wild morals and, if the texts are read carefully enough, the werewolf does emerge as a metaphor for deviant male sexuality. Dutch informants were arguably slightly more open about this than the Germans were, since their narratives lacked the eating metaphor (and they were also interviewed at a later period than the Germans). It was reported in the 1960s, for example, that a farmer in the Dutch village of Meerkerk had impregnated his serving maid and, that together, they had murdered the child. This farmer was also rumoured to "werewolf," which, in this case concerned a heterosexual relationship (Kooijman 1988 , nos 165 and 166). Although the link between werewolfing and impregnating the maid is not explicitly made in these texts, this type of occurrence was already recorded from an area nearby, in the early twentieth century (Ramondt 1912, 162).
Werewolves were also said to assault women (collection Linssen no. 7.4). When a girl disappeared in the neighbourhood of 's-Hertogenbosch, she was rumoured to have been taken by a werewolf (Survey 1937, L177). A story from Dutch Flanders about a werewolf who had attacked a boy, ended with the remark that, although werewolves no longer existed, men still assaulted boys (collection De Vries no. 8.2). The werewolf was also described as a "bad bloke who takes children" (Survey 1937, E91b). Warning children about human predators seems more relevant than warning them to stay away from wheat-fields (where most of the bogeymen were located)-the possibly implied sexual threat that bogeymen embodied was overlooked by folklorists. Werewolf legends also reveal other characters considered deviant, such as, peeping toms (collection Linssen no. 9.1; collection Krosenbrink no. 237.3), an exhibitionist, transvestites (collection Linssen no. 98.4), and even a man committing incest. There is also a hint at abortion in an account of a respondent from east Groningen who wrote: "Dark tales about miscarriages are connected with this ..." (Survey 1937, C163).

German informants rarely made explicit sexual inferences in their accounts, or at least they were not recorded or published by the folklorists, if they did so. As was the case in the Netherlands, it cannot be assumed that sexuality was directly referred to in any conversation with a folklorist. Nor is this likely to have been necessary since people (the folklorist excluded) readily understood the back rider as a (homo)sexual creature, while the Werewolf Husband legend gave them the opportunity to discuss (hetero)sexual assaults, and the Hungry Farmhand narrative was understood as denoting sodomy. The probable sexual meaning of the counter measure of hitting a werewolf below the belt, as was advised in Lower Saxony, was probably clear enough, too. It was also said that if a girl discovered her boyfriend to be a Böxenwolf she would break off the engagement. There are, moreover, some references to the werewolf's dislike of the marital bed. In Jülich it was said that he put a broomstick in bed next to his wife and went out (Henßen 1955 no. 166a). In Minden, the werewolf was recognised because he "stays cool in bed" (ZA 851622), and in Lower Saxony, according to material recorded by an early twentieth-century researcher, "It even happened that he crept into the beds of other people" (Meyer 1927, 224). A number of the unpublished legends from Holstein deal with the theme of "the werewolf in bed." These texts relate how a werewolf, who has been out of the house, creeps back into bed just in time, but is given away by his (or her) tail which is still hanging out of the bed. This refers to the equation of tail with penis, which was already evident in the sixteenth century.
If the werewolf's main activity was sexual, it would certainly explain his irrepressible sexual urge mentioned in the legends. A werewolf had to put on a skin (or a bag, or a sheet) in order to werewolf, and he was thought to be unable to control his sexual drive. Bodens mentioned "an obsession, from which the person involved cannot escape," and other informants told him that it was something "like an illness." "He had to do it, he could not do otherwise" (Bodens 1934, 299; 1937, no. 738). In Lippe it was said that he "had to" ride people (Scheffler 1994, 280). The trouser-wolf from Westphalia was likewise driven by an internal force, which, according to the legends, was irresistible (Peuckert 1966, no. 1396II). The same was the case in the southeastern parts of the Netherlands; the Oven Legend primarily describes a possible outcome of the werewolf's internal struggle. Furthermore, on a number of occasions, people in the Netherlands pointed to men 
in the neighbourhood who were known to be werewolves. As a respondent to the 1937 Dutch survey remembered it: "When I was young, there was such a one where we lived, he was called the werewolf. Several people had to carry him" (Q102). Without exception, such people were described as being asocial; that is, odd, solitary, introverted, wayward, detached, surly, obnoxious or godless. The one thing that was not explicitly mentioned was that they were sexual deviants. As a fruit grower from Bunnik (near Utrecht) put it: "He was a wild fellow who led a bad life and with whom nobody wanted to mix" (Heupers 1979-84, no. 3413). A publican from eastern Guelders, who was also familiar with the saying, that to werewolf was worse than to witch, mentioned that such people were given a name, which referred to the male member (Krosenbrink 1968, no. 80.5). [5]

\section{Hints of History}

Doubts about the authenticity of the back-riding werewolf were not completely unjustified, even if they denied the content of many werewolf legends. They were based, however, on a false assessment of the werewolf's history in the area dealt with in detail here. This is not the place for an extensive treatment of early modern werewolf texts, and I will thus only outline here some of the conclusions to be drawn from them (see de Blécourt, forthcoming). During most of the sixteenth century the concept of the werewolf was practically unknown. When it was introduced in the 1590s, by way of criminal trials, the fascination with it spread rapidly, starting in Cologne and the County of Nassau, and reaching German Soest in 1590, Mechelen in 1592, and Utrecht in 1595. Belief in it intensified in the intervening regions during the following decades. Because of particular rules of evidence in the trials, it was easier to determine whether someone was a werewolf than a sodomite, even when his actions had been the same. Werewolves thereby merged with, but did not necessarily replace, existing notions about male sexual deviancy, such as those connected with the back rider. In areas which remained free of werewolf trials, back riders kept their own names. In that sense, back-riding werewolves were not "original"; but neither were werewolves themselves. As to the Werewolf Husband/Lover and the Hungry Farmhand legends-if they did indeed stem from Southern Scandinavia, they may have been introduced into Germany by Swedish troops during the seventeenth century, thus adding stories to notions that were just then enjoying heightened attention.

\section{Notes}

[1] The localities for this story are Bibesheim and Wernigerode. In his text Jacob Grimm added a reference to a werewolf trial, which is omitted here.

[2] This may inspire others to carry out research about werewolf legends elsewhere, notably in Alpine France and adjacent Italy, Scandinavia, and along the southern reaches of the Baltic where they have all distinctive characteristics. "Werewolves" from the lands south of the Carpathians deserve special attention (notwithstanding Senn's 1982 study), since they appear to be either German imports or so tightly intertwined with notions of "vampires" that they can hardly be called werewolves, in the English sense (compare Sommer 1988).

[3] The unpublished collections of Brouwers, Eggen, Krosenbrink, Linssen, Jaarsma and De Vries, as well as the forms of the 1937 folklore survey, can all be found at the Meertens Institute in
Amsterdam. The collections of Bodens and Meyer are available in Marburg. See for Flanders (for example Daras, Daniels, and Roeck): www.volksverhalenbank.be.

[4] An additional indication of the sexual innuendo in the legend is shown by the Eastern European variant in which the man's "tail" has to be removed to save the relationship (Cammann and Karasek 1981, 91).

[5] The dialect term mentioned is Piemansvolk; that is, people defined by their penis.

\section{References Cited}

Bartsch, Karl. Sagen, Märchen und Gebrauche aus Mecklenburg. Wien: Braumüller, 1879.

Berg, Marcel van den. Volksverhalen uit Antwerpen. Utrecht and Antwerpen: Het Spectrum, 1981.

. De volkssage in de provincie Antwerpen in de 19de en 20ste eeuw. Gent: Koninklijke Academie voor Nederlandse Taal- en Letterkunde, 1993.

Blécourt, Willem de. Volksverhalen uit Nederlands Limburg. Utrecht and Antwerpen: Het Spectrum, 1981.

- "Bedding the Nightmare. Somatic Experience and Narrative Meaning in Dutch and Flemish Legend Texts." Folklore 114 (2003): $227-45$.

. "The Werewolf, the Witch, and the Warlock." In Witchcraft and Masculinities, ed. Alison Rowlands (forthcoming).

Bodens, Wilhelm. "Xantener Sagen." Rheinische Vierteljahrsblätter 4 (1934): 290-302.

—. Sage, Märchen und Schwank am Niederrhein. Bonn: Röhrscheid, 1937.

Cammann, Alfred, and Alfred Karasek. Volkserzählung der Karpatendeutschen—Slowakei. Marburg: Elwert, 1981

Christiansen, Reidar Th. The Migratory Legends. FFC 175. Helsinki: Suomalainen Tiedeakatemia, 1958.

Daras, Hervé, "Onderzoek naar de sagenmotieven in het hart van de Antwerpse Kempen". Ph.D. diss., Catholic University of Leuven, 1964.

Dinnissen, M. H. Volksverhalen uit Gendt. Amsterdam: Meertens Instituut, 1993.

Dekker, A. J., and J. J. Schell. De volkskundevragenlijsten 1-58 (1934-1988) van het P.J. MeertensInstituut. Amsterdam: Meertens Instituut, 1989.

Franz, Heinrich. "Der Werwolfglaube unter besonderer Berücksichtigung der hessischen Überlieferung." Hessenland. Hessisches Heimatblad 31 (1917): 255-60.

Grimm, Jacob, and Wilhelm Grimm. Deutsche Sagen. München: Winkler, 1976. Originally published in 1891.

Grober-Glück, Gerda. "Aufhocker und Aufhocken nach den Sammlungen des Atlas der deutschen Volkskunde: ein Beitrag zur deutschen Sagenkunde." Rheinisches Jahrbuch für Volkskunde 15/16 (1964/65): 117-43

Grüner, Gustav. Waldeckische Volkserzählungen. Marburg: Elwert, 1964.

Henßen, Gottfried. Sagen, Märchen und Schwänke des Jülicher Landes. Bonn: Röhrscheid, 1955.

Hertz, Wilhelm. Der Werwolf: Beitrag zur Sagengeschichte. Stuttgart: Kröner, 1862.

Heupers, Engelbert. Volksverhalen uit Gooi- en Eemland en van de westelijke Veluwe. Amsterdam: Meertens Instituut, 1979-84

Höck, Alfred. "Bemerkungen zum 'Werwolf' nach hessischen Archivalien." Hessische Blätter für Volks und Kulturforschung 18 (1985): 71-5. 
Kaufmann, Otto. "Oberbergische Volkserzählungen." Rheinisch-Westfälische Zeitschrift für Volkskunde 12 (1965): 1-85.

Kooijman, Henk. Volksverhalen uit het grensgebied van Zuid-Holland, Utrecht, Gelderland en NoordBrabant. Amsterdam: Meertens Instituut, 1988.

Krosenbrink, Henk. De oele röp: Achterhookse volksverhalen. Aalten: De Boer, 1968.

Kuhn, Adalbert. Märkische Sagen und Märchen. Berlin: Reimer, 1843.

Kvideland, Reimund, and Henning K. Sehmsdorf, eds. Scandinavian Folk Belief and Legend. Oslo: Norwegian University Press, 1991.

Lohmeyer, Karl. Die Sagen des Saarbrücker und Birkenfelder Landes. Saarbrücken: Hofer, 1920

Lyncker, Karl. Deutsche Sagen und Sitten in hessischen Gauen. Cassel: Bertram, 1854.

Meyer, E. H. Wilh. Ein niedersächsisches Dorf am Ende des 19. Jahrhunderts. Bielefeld: hist. Verein Ravensberg, 1927.

Meyer, Gustav Fr. Schleswig-holsteiner Sagen. Jena: Diederichs, 1929.

Müller, Konrad. Die Werwolfsage: Studien zum Begriff der Volkssage. Karlsruehe: Macklotsche Verlag, 1937.

Odstedt, Ella. Varulven $i$ Svensk Folktradition. Uppsala and Kobenhavn: Lundeqvist and Munksgaard, 1943 (with German summary).

Peuckert, Will-Erich. Niedersächsische Sagen. II. Göttingen: Schwartz, 1966.

Pfister, Hermann von. Sagen und Aberglaube aus Hessen und Nassau. Marburg: Elwert, 1885.

Ramondt, Marie. "Iets over den weerwolf in de Betuwe." Volkskunde 23 (1912): 161-3.

Roeck, F. De "Nederlandse weerwolfsage in de negentiende en twintigste eeuw." Unpublished Ph.D. diss., Catholic University of Leuven 1967.

. "Volkskundig onderzoek naar de weerwolfsage." Wetenschappelijke tijdingen 27 (1968) $145-60$.

Sartori, P. "Werwolf." Zeitschrift des Vereins fiur Rheinische und westfälische Volkskunde 20 (1923): 79-80.

Scheffler, Jürgen. "Hexenglaube in der ländlichen Gesellschaft." In Hexenverfolgung und Regionalgeschichte: Die Grafschaft Lippe im Vergleich, eds. Gerd Schwerhoff, Gisela Wilbertz, and Jürgen Scheffler 263-296. Bielefeld: Verlag für Regionalgeschichte, 1994.

Schell, Otto. Bergische Sagen. Elberfeld: Baedekersche Buchhandlung, 1897.

Senn, Harry. Were-Wolf and Vampire in Romania. Boulder: East European Monographs, 1982

Simonsen, Michèle. "La variabilité dans les légendes: les récits danois sur les loupsgarous." In $D^{\prime} u n$ conte ... à l'autre: la variabilité dans la littérature orale, ed. Veronika Görög-Karady. 181-9. Paris: CNRS, 1990.

Sommer, Inge. “'Krechintza zwischen den Zähnen.' Aspekte der Siebenbürgisch-Saksischen Prikulitschsage." Neue Literatur: Zeitschrift des Schriftstellerverbandes der SR Rumänien 39, no. 3 (1988): 51-5.

Strackerjan, Ludwig. Aberglaube und Sagen aus den Herzogtum Oldenburg. Oldenburg: Stalling, 1909. Originally published in 1868

Strube, Thorsten. “... 'dat was en Mann, de sich en Koefell ummehänge': Betrachtungen zum Werwolfmotiv in der Niederdeutschen Erzähltradition." Quickborn. Zeitschrift für plattdeutsche Sprache und Literatur 90, no. 4 (2000): 16-26.

Thompson, Stith. Motif-Index of FolkLiterature. 6 vols. Copenhagen: Rosenkilde and Bagger, 1955-58. Tinneveld, A. Vertellers uit de Liemers. Wassenaar: Neerlands Volksleven, 1976.
Zaunert, Paul. Hessen-Nassauische Sagen. Jena: Diederichs, 1929.

Zender, Matthias. Sagen und Geschichten aus der Westeifel. 3rd ed. Bonn: Röhrscheid, 1980.

\section{Biographical Note}

Willem de Blécourt is a research fellow at the Meertens Institute, Amsterdam. He has published extensively on European witchcraft (fifteenth-twentieth centuries) and on irregular healers in the Netherlands (nineteenth twentieth centuries). He is currently writing a book on werewolves on the European continent, and another on werewolves in films. 